\title{
Participation and Bridging: Involving Etrepreneurs in the Management of the EU Rural Economy
}

\author{
TETYANA O. ZINCHUK ${ }^{1}$, LIUDMYLA V. TARASOVYCH ${ }^{2}$, MARYNA I. YAREMOVA ${ }^{3}$, \\ TETIANA V. USIUK ${ }^{4}$, OLEKSANDR D. KOVALCHUK ${ }^{5}$ \\ ${ }^{1}$ Department of International Economic Relations and European Integration, POLISSIA NATIONAL UNIVERSITY,

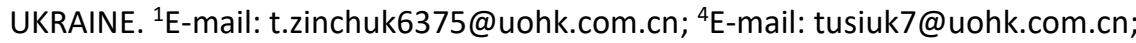 \\ ${ }^{5} \mathrm{E}$-mail: od-kovalchuk@uohk.com.cn \\ 2Department of Marketing, POLISSIA NATIONAL UNIVERSITY, UKRAINE. E-mail: Iv-tarasovych@nuos.pro \\ ${ }^{3}$ Department of Economics and Entrepreneurship, POLISSIA NATIONAL UNIVERSITY, UKRAINE. \\ E-mail: m.yaremova@tanu.pro
}

\begin{abstract}
It has been proved that the implication of the European experience in the development of the rural economy in Ukraine is seen as a necessary attribute of the implementation of its ambitions to participate in the global process of sustainable development. It is emphasised that the asset of EU member states in forming the imperatives of sustainable development is to enhance the role and ensure the participation of all stakeholders in the management of the rural economy. The content of the stakeholder-oriented approach is characterised, and its imperatives in the context of agricultural management are identified. It has been substantiated that the stakeholders of rural economic development are any individuals, communities, groups, or institutions interested in the effective results of this process, which either directly affect them, or which they influence. Identified groups of rural development stakeholders: local government (public sector); business (private sector); household sector; non-governmental non-profit organisations (civil society). They influence or may be affected by decisions of any level of management hierarchy that should be taken into account under the conditions of configuration of their strategic orientations in mechanisms of management of the rural economy. To assess the degree and strength of the impact of stakeholders on the development of the rural economy, an appropriate matrix was formed, which allowed to determine their interests and possible strategic interactions in terms of key, secondary, supportive and passive groups of stakeholders. This is necessary to predict both the partnership and the competitive nature of cooperation, as stakeholders have (potentially have) different interests (economic, social, environmental, informational) and limited or unevenly distributed resources to implement these interests (financial, labour, intellectual, innovative, technological, informational, property, personnel, administrative, etc.). The profile of interests and influence of stakeholders on the development of the rural economy was built with a focus on the territorial community as an object of local impact. The mechanisms and features of attracting entrepreneurs as key stakeholders in rural economy management on the basis of bridging, the principles of which provide systematic, consistent, and well-established cooperation towards the implementation of common strategic objectives, interests, and goals of the rural economy. The possibilities of strategic partnership through the inclusive participation of all stakeholders in the implementation of projects and territorial development plans are outlined. The advantages of implementation in Ukraine of the European experience of attracting stakeholders in management of rural economy have been proven.
\end{abstract}

Keywords: rural economy, entrepreneurship, stakeholders, bridging, inclusive rural transformation.

JEL Classification: P17, P11, F15. 


\section{Introduction}

Ukraine's European integration course strengthens the need and at the same time expands the possibilities of using modern tools of rural management as a keynote of viability and livelihood of rural areas. One such tool is bridging (strategic partnership) based on the inclusive participation of all stakeholders in the implementation of various projects and territorial development plans. The timeliness of its application is due to the fact that the progressive socio-economic transformations in rural areas are interested not only in rural areas, but also a number of agents who, on the one hand, influence this process and accompany it, on the other - depend entirely on it. Understanding the role and value of the participation of all stakeholders in the management of the rural economy in the context of shaping the imperatives of sustainable development is an indisputable asset of EU member states.

The driver of rural development is entrepreneurship. Entrepreneurship is the main source of filling the budgets of rural communities; the sphere of income formation of rural residents, which contributes to improving the welfare and quality of their lives; driving force for food security of the country; a tool for building chains of agrarian business, which expands the boundaries of participation of rural producers in the formation of added value of their own products, etc. From this standpoint, it is timely to direct scientific research in line with justifying the need, opportunities and advantages of attracting entrepreneurs as stakeholders in managing the rural economy; determining the levers and significance of their influence; developing tools for coordinating cooperation; establishing the degree of consistency and the nature of meeting their interest. This approach will guarantee the high quality of inclusive rural transformation in Ukraine, as is the case in EU countries.

The foundations of stakeholder theory were laid in the 1960s highlighted the possibilities of its use within the framework of the functioning of certain spheres or objects of social development. Today, it is an indispensable area of research in the fields of economics and strategic management, and its basic provisions are considered a valuable scientific achievement in the context of evolution from neoclassical to entrepreneurial paradigms. The work of well-known foreign scientists, including E. Freeman (1984) author of the famous book "Strategic Management: A Stakeholder Approach", in which stakeholders are considered in the "original model of the firm", is devoted to the formation of stakeholder theory, substantiation of attempts to imply it in the concept of strategic management, the degree of their influence, individual requests and place in the strategy of business development are substantiated; T. Donaldson, M. Clarkson, J. Post and S. Sachs (2002) consider relationships with stakeholders as a dominant management system and a source of organisational wealth; L. Preston (2004) emphasised that people and groups that benefit only when the organisation as a whole bears losses are not stakeholders, although they may be interested in its actions; Mr. D'Anselmi (2011) considered stakeholders to be people or groups of people who voluntarily or unintentionally exposed themselves to the risk posed by the firm's actions, i.e. viewed them through the prism of risk-taking.

In the empirical-analytical plane of modern scientific insights, the stakeholder-oriented approach is considered to be an effective tool for managing the rural economy, primarily through the mechanisms of partnership participation. In particular, the development of an inclusive rural economy, primarily through the implementation of bridging mechanisms, is reflected in the works of J. Gupta et al. (2015), N. Pove, M. Ross-Tonen. The implementation of entrepreneurial initiative in the process of rural economy development on the basis of cooperation and partnership is studied by J. Ramanauskas et al. (2017), J. Zhukovskis and others. The content and features of resource and spatial contexts of bridging in rural entrepreneurship are studied by S. Korsgaard, et al. (2018). Some aspects of strategic partnership as a tool for revitalising rural business are revealed in the works of $\mathrm{M}$. Lopez, A. Cazorla, M. Panta (Lopez et al., 2019; Méndez et al., 2020). Peculiarities of the implication of the entrepreneurial component in the process of formation and development of the rural economy on the basis of bridging are reflected in the works of K. Wigren-Kristofersen et al. (2019), E. Brundin, K. Hellerstedt, G. Alos, J. Grande. The imperatives of rural transformation from the standpoint of a stakeholder-oriented approach are thoroughly studied by C. Trivelli, \& J. Berdegué (2019). 
It should be noted that until recently, the stakeholder approach was not the object of scientific interest on the part of Ukrainian scientists, and existing developments concerned the study of this problem at the level of individual actors, mainly in the perspective of investment projects. Researchers focused on the ability to meet the interests of owners, shareholders, employees, buyers, consumers, suppliers, i.e. those agents who directly formed the internal business environment of business structures. Attention to this issue has grown with the formation of the rural economy and the rapid development of the corporate type of entrepreneurship, the important features of which are a high degree of integration and social responsibility for the results of their work.

Currently, the objects of special research in this area are increasingly the processes of management and planning of rural development and individual territorial units, including taking into account the interests of stakeholders (Dashchuk, 2013; Vasylchenko et al., 2015; Horban, 2016; Skydan et al., 2019); managing the implementation of entrepreneurial potential in line with socio-economic rural transformations (Shkromyda, 2014; Belokon et al., 2016; Kravchuk et al., 2017; Smachylo et al., 2017; Zinovchuk, \& Kopytova, 2018; Tkachuk et al., 2019; Tryfonova, 2019); stakeholder management and bridging for effective project management in the context of Ukraine's integration into the European and global business space (Khoroshun, \& Nikiforova, 2017; Levchenko, 2019); realisation of partnership ambitions through social responsibility of business, management of bridging at regional and local levels (Lahuta, 2017; Rybak, \& Azarova, 2017); mechanisms of inter-municipal partnership within the framework of formation of strategies of development of territorial communities (Vasylchenko et al., 2015); models of implementation of various business projects based on rural communities, promotion of youth and women's entrepreneurship in rural areas under the conditions of institutional transformations (Borodina et al., 2015; Zinchuk et al., 2017; Kutsmus, 2018; Zhosan, 2020; Carrión et al., 2020).

Noting the value of scientific achievements of foreign and Ukrainian researchers in the field of issues raised, it should be noted that in the implementation of Ukraine's European ambitions increases the need to justify the opportunities and feasibility of stakeholders, including entrepreneurs, in managing rural economies.

\section{Materials and Methods}

The theoretical and methodological basis of this study are general principles of economic research, fundamental principles of economic theory, conceptual foundations of stakeholder management theory, scientific achievements of Ukrainian and foreign experts on rural management on a partnership basis.

In the process of writing this paper, general and special scientific methods were used. In particular, induction and deduction were used to generalise and systematise the basic provisions of the theory of stakeholder management based on their extrapolation into the plane of rural management. The monographic method was used to justify the possibility of involving certain groups of stakeholders in the management of the rural economy, and grouping - to differentiate them in the context of result orientation. The historical-economic method served to study the peculiarities of the implication of the European experience in the process of formation of the Ukrainian model of rural economy management. Comparison of indicators of rural economic development in Ukraine and EU member states was carried out on the basis of comparative analysis. The scientific abstraction was used to generalise scientific results and formulate conclusions through in-depth knowledge of rural management processes. Using the tools of stakeholder analysis, in particular the matrix method. First, a matrix of stakeholders of rural development was formed to assess the possibilities of managing this process in the case of assessing the levels of influence and interest of stakeholders in the desired result. Second, a profile of stakeholder interests and influence on the development of the rural economy was built with a focus on the territorial community as an object of direct influence. With the help of tabular and graphical methods, a visual interpretation of the research results was carried out.

The purpose of the paper is to substantiate the tools for attracting entrepreneurs as stakeholders in rural development and to outline the possibilities of applying the European experience of managing 
this process. The objectives are: 1 ) to characterise the content of the stakeholder-oriented approach and identify its features in the context of rural management based on the use of stakeholder analysis tools; 2) substantiate the mechanisms for attracting entrepreneurs as key stakeholders in the management of the rural economy on the basis of participation and bridging; 3 ) to prove the need to implement in Ukraine the European experience of involving stakeholders in the management of the rural economy.

\section{Results and Discussion}

Current trends in the world economy in the direction of sustainable development of society indicate a change in the economic paradigm in favour of agriculture and rural areas. The shift in emphasis towards the rural economy occurred due to a change in views on its role in ensuring food security and competitiveness of countries, the establishment of high standards of quality of life in rural society and the achievement of rural potential. The need to ensure the development of the rural economy and agriculture as a key component of it is emphasised in the Global Sustainable Development Goals adopted by the UN Summit for 2015-2030. This issue is also included in the new UN General Assembly Action Plan to bring the world on the trajectory of sustainable development (United Nations Ukraine, 2015). This outlines the timeliness of developing measures to manage the rural economy with the involvement of all stakeholders in this process at different levels of the management hierarchy. Particular consideration should be given to the identification of management levers at the local and regional levels, given the need to use the European experience of rural development, which involves the implementation of the initiative from below.

The European experience of involving stakeholders in the management of the rural economy is considered today to be one of the most effective, given the possibility of building constructive and transparent cooperation within a specific socio-economic system. The management model of participation configures a wide range of activities, declared in a number of national and regional programmes and standards, each of which to some extent outlines the mechanisms of coordination and cooperation of stakeholders. The standards of European management practice contain the basic principles of building a model of effective interaction with stakeholders. Stakeholder theory makes it possible to manage the system of corporate social responsibility of business. This leads to the presentation of its key postulates in numerous domestic and international, including European standards, which interpret the principles of the modern economic system.

For example, ISO 26000: 2010 identifies stakeholder as a person or group of persons interested in any decisions or actions of an organisation. Interactions with stakeholders are interpreted as actions taken to enable dialogue between the organisation and one or more stakeholders, parties in order to form an information platform for management decisions (International Organisation for Standardisation, 2010). The International Project Management Organisation IO4RM separates stakeholder management into a new independent field of knowledge, treating stakeholders as "individuals, groups or organisations that may influence, be influenced or perceive themselves to be affected by a project decision, operation, or outcome" (Project Management Institute, 2013).

Theoretical and practical value is defined by the AA 1000 AccountAbility Series of International Standards, which configure the basic principles used by global businesses, public and private organisations to ensure leadership and performance in the areas of accountability, responsibility and sustainability. Their value is seen as an arsenal of effective tools that have proven their effectiveness in shaping strategies for sustainable development, management, and business. The AA 1000 Series of Standards provides clear and practical measures for: a) development, analysis and implementation of sustainable development initiatives (AccountAbility, 2018); b) creating and conducting inclusive stakeholder engagement practices related to sustainability (AccountAbility, 2015); c) ensuring confidence in reporting on progress towards sustainability goals (AA 1000 AS v3). In particular, the International Standard for Stakeholder Interaction AA 1000 SES defines three basic principles of stakeholder interaction: inclusiveness, materiality, speed of response, as well as the degree of such interaction with a clear justification of the objectives of each: 1 ) interaction to reduce the problem as a 
result of pressure and has a local effect; 2) systematic interaction to manage risks and improve understanding of stakeholder expectations; 3) comprehensive strategic cooperation to ensure sustainable competitiveness (AccountAbility, 2015).

The peculiarity of involving entrepreneurs as stakeholders in development of rural economy is that the process of their identification is based on the interests of several levels of stakeholders. First of all, it is necessary to consider the essence of the phenomenon of rural economy, namely:

1) rural economy is a system of industries and activities operating in rural areas - agriculture, forestry, fisheries, water management, mining, processing and other industries, construction, services, infrastructure, etc. That is, there is a multicriteria of the object sphere of study from the standpoint of industry affiliation and type of activity of business entities;

2) the process of rural economy development is provided by economic entities (enterprises, institutions, organisations, individuals - entrepreneurs, other economic units, households, communities, etc.) located in rural areas. That is, there is a multicriteria of the subjective sphere of study in the perspective of assessing the satisfaction of their target interests;

3) rural economy is a complex dynamic system of open type, the affiliation of which, although defined by the geographical boundaries of rural areas, but is not limited to relationships with other entities and institutions outside the contours of local rural areas (regional, national, international level);

4) taking into account and satisfying the interests of all stakeholders in the process of forming strategic directions of territorial development simultaneously contributes to the growth of the local economy and the improvement of its image (both at the local and international levels). Growth in the economic sphere is a determinant of the development of territories and communities, and therefore - indicates the functional and structural complementarity of the parameters of rural development in general;

5 ) the process of interaction of stakeholders in the development of rural economy of all levels of subject-object affiliation is characterised by systemic, consistent and unpredictable external challenges, which emphasises the need to use marketing tools in the analysis and management of stakeholders.

Therefore, stakeholders in rural economic development are any individuals, communities, groups, or institutions interested in the effective results of this process, which either directly affect them or which they affect in any way (positively or negatively). The key lever of influence is the appropriate capital - financial, social, human, intellectual, resource, etc. In turn, investing capital is accompanied by different degrees of risk, because common, at first glance, for all stakeholders, the goals of rural development can be achieved in different ways that will be beneficial to some and not beneficial to others, i.e. there is a problem of conflict interests in the process of forming the result of cooperation. In this sense, the coherence of the interests of stakeholders, whose resources affect the expected benefits, as well as the effective management of stakeholders are important elements in ensuring the effectiveness of the management system of rural development.

Stakeholders of rural development are represented by four groups: 1) local government (public sector); 2) business (private sector); 3) household sector; 4) non-governmental non-profit organisations (civil society) (Table 1).

It should be noted that each of the represented groups of stakeholders has its own vision of the future, specific priorities, unique resources, and therefore - has individual levers of influence on the management of the rural economy. As a result, each of them participates in a special way in the formation of the strategy of local economy development, as well as stimulates and motivates other parties to its implementation for the formation of appropriate parameters of growth. In each of the stakeholder groups, it is necessary to identify those representatives (individuals or organisations) who may influence the development process (from planning to monitoring and control of the results obtained) or who are primarily affected by decisions about development imperatives. 
Tetyana O. Zinchuk, Liudmyla V. Tarasovych, Maryna I. Yaremova, Tetiana V. Usiuk, Oleksandr D. Kovalchuk

Table 1 Separation of stakeholders in rural development from the standpoint of result

\begin{tabular}{|c|c|c|}
\hline $\begin{array}{c}\text { Group of } \\
\text { stakeholders }\end{array}$ & Representatives of stakeholders & Key focus on results \\
\hline $\begin{array}{l}\text { Public sector } \\
\text { (local government) }\end{array}$ & $\begin{array}{l}\text { - officials of the territorial community } \\
\text { - local governments and their structural units } \\
\text { - district, region, and state administrations and agencies } \\
\text { responsible for planning and managing the development of } \\
\text { rural areas and the economy and performing regulatory } \\
\text { functions } \\
\text { - research institutions, state universities, colleges } \\
\text { - public investors }\end{array}$ & $\begin{array}{l}\text { Creation of public } \\
\text { goods at the expense } \\
\text { of part of the income of } \\
\text { the household sector } \\
\text { and the business } \\
\text { sphere }\end{array}$ \\
\hline $\begin{array}{ll}\text { Private } & \text { sector } \\
\text { (business) } & \end{array}$ & $\begin{array}{l}\text { - large, medium, and small enterprises, private entrepreneurs } \\
\text { - private investors } \\
\text { - banks, credit unions and other financial institutions } \\
\text { - Chambers of Commerce and Industry and other business } \\
\text { associations } \\
\text { - agencies and associations of entrepreneurs, intermediaries } \\
\text { for business support and development (business centres, } \\
\text { business development funds, etc.) }\end{array}$ & $\begin{array}{l}\text { Getting the maximum } \\
\text { profit, implementation } \\
\text { of entrepreneurial } \\
\text { initiative }\end{array}$ \\
\hline Household sector & $\begin{array}{l}\text { - individuals (rural residents) } \\
\text { - rural community as a whole }\end{array}$ & $\begin{array}{l}\text { Ensuring a high quality } \\
\text { of life and living } \\
\text { conditions through } \\
\text { access to public goods }\end{array}$ \\
\hline $\begin{array}{l}\text { Non-governmental } \\
\text { organisations (civil } \\
\text { society) }\end{array}$ & $\begin{array}{l}\text { - bodies of self-organisation of the population } \\
\text { - local schools, preschools and cultural institutions, health care } \\
\text { facilities } \\
\text { - public organisations and associations representing the } \\
\text { interests of the rural community } \\
\text { - mass media } \\
\text { - organisations and associations that focus on the development } \\
\text { of the territory, community } \\
\text { - trade unions and other professional organisations }\end{array}$ & $\begin{array}{l}\text { Accumulation of social } \\
\text { capital, social growth }\end{array}$ \\
\hline
\end{tabular}

Source: Vasylchenko et al., 2015

Table 2 Instruments of stakeholder analysis of management and development of rural economy

\begin{tabular}{|l|l|}
\hline \multicolumn{1}{|c|}{ Instrument } & \multicolumn{1}{|c|}{ Characteristics } \\
\hline Stakeholder matrix & $\begin{array}{l}\text { The degree and strength of the influence of stakeholders on economic } \\
\text { development is assessed, their interests and possible strategic } \\
\text { interactions are determined. }\end{array}$ \\
\hline Mitchell Agle Wood model & $\begin{array}{l}\text { It is based on the identification of stakeholders depending on the } \\
\text { combination of several attributes and the division into latent (those that } \\
\text { are waiting) and categorical. The typology is based on three factors: } \\
\text { legality, significance, urgency. }\end{array}$ \\
\hline Stakeholder's Map & $\begin{array}{l}\text { Graphical interpretation of different relationships with stakeholders. } \\
\text { Visualisation of stakeholder groups is carried out by the level of interest } \\
\text { "high/low" and the level of influence "strong/weak". }\end{array}$ \\
\hline $\begin{array}{l}\text { Stakeholder engagement standard } \\
\text { "PA 1000 SES }\end{array}$ & $\begin{array}{l}\text { It involves the identification of stakeholders in relation to the power they } \\
\text { hold and the dynamism of their position. }\end{array}$ \\
\hline $\begin{array}{l}\text { Three Concentric Circles Model } \\
\text { emergence, the degree of closeness, the degree of dependence must be } \\
\text { taken into account. }\end{array}$ & $\begin{array}{l}\text { Display in the form of three concentric circles of the resource base } \\
\text { (internal environment), sectoral structure and socio-political situation. }\end{array}$ \\
\hline Savage model & $\begin{array}{l}\text { It is used to assess the likelihood of harm to a stakeholder, as well as the } \\
\text { potential for mutually beneficial cooperation. Appropriate strategies for } \\
\text { negotiation, defence, involvement, monitoring. }\end{array}$ \\
\hline $\begin{array}{l}\text { A. Mendelow model } \\
\text { ("Power - Interest" matrix) }\end{array}$ & $\begin{array}{l}\text { Provides classification and grouping of stakeholders by their relation to } \\
\text { the power they possess and the extent their interests (influence on } \\
\text { management decisions - strong/weak; interest - high/low). The degree of } \\
\text { influence of the stakeholder (integrated indicator) is determined by both } \\
\text { his power and interest (their product). }\end{array}$ \\
\hline $\begin{array}{l}\text { Creating a system of compliance indicators that allows to describe the } \\
\text { interaction with stakeholders, using two types of relationships, } \\
\text { contributions and stimulus responses. }\end{array}$ \\
\hline
\end{tabular}

Source: AccountAbility, 2015; Smachylo et al., 2017; Tryfonova, 2019 
The choice of tools for managing the interaction of stakeholders depends on the analysis of their feasibility under specific conditions of the system. Identification of target groups of stakeholders in the management and development of rural economy should be carried out using stakeholder analysis, the portfolio of which is represented by various marketing models and tools (Table 2).

In the context of this study, the visualisation of the application of these tools was carried out using a matrix of stakeholders in rural development (Figure 1). This is due to the need to adequately assess the possibilities of managing this process in the case of assessing the level of their impact and the level of interest in the desired result for each participant. According to the matrix, 4 groups of stakeholders are outlined - key, secondary, supportive, passive. Group I - key stakeholders: stakeholders with a high level of interest in the development of the rural economy and a high level of managerial influence on this process. Therefore, it is in their competence to directly participate in making strategically important management decisions and apply their own levers of influence. It is necessary to consider all possible options for the fullest satisfaction of the interests of stakeholders in this group, including on the basis of bridging. In the context of this study, the entrepreneurial component of influence and interest in the development of the economy is emphasised, i.e. directly entrepreneurs and representatives of the private sector (business). Group II - secondary stakeholders: stakeholders with a high level of influence and low interest in rural development also need to satisfy their interests. It is advisable to agree with such stakeholders only on the most important strategic steps.

Figure 1 Matrix of stakeholders in rural economy development

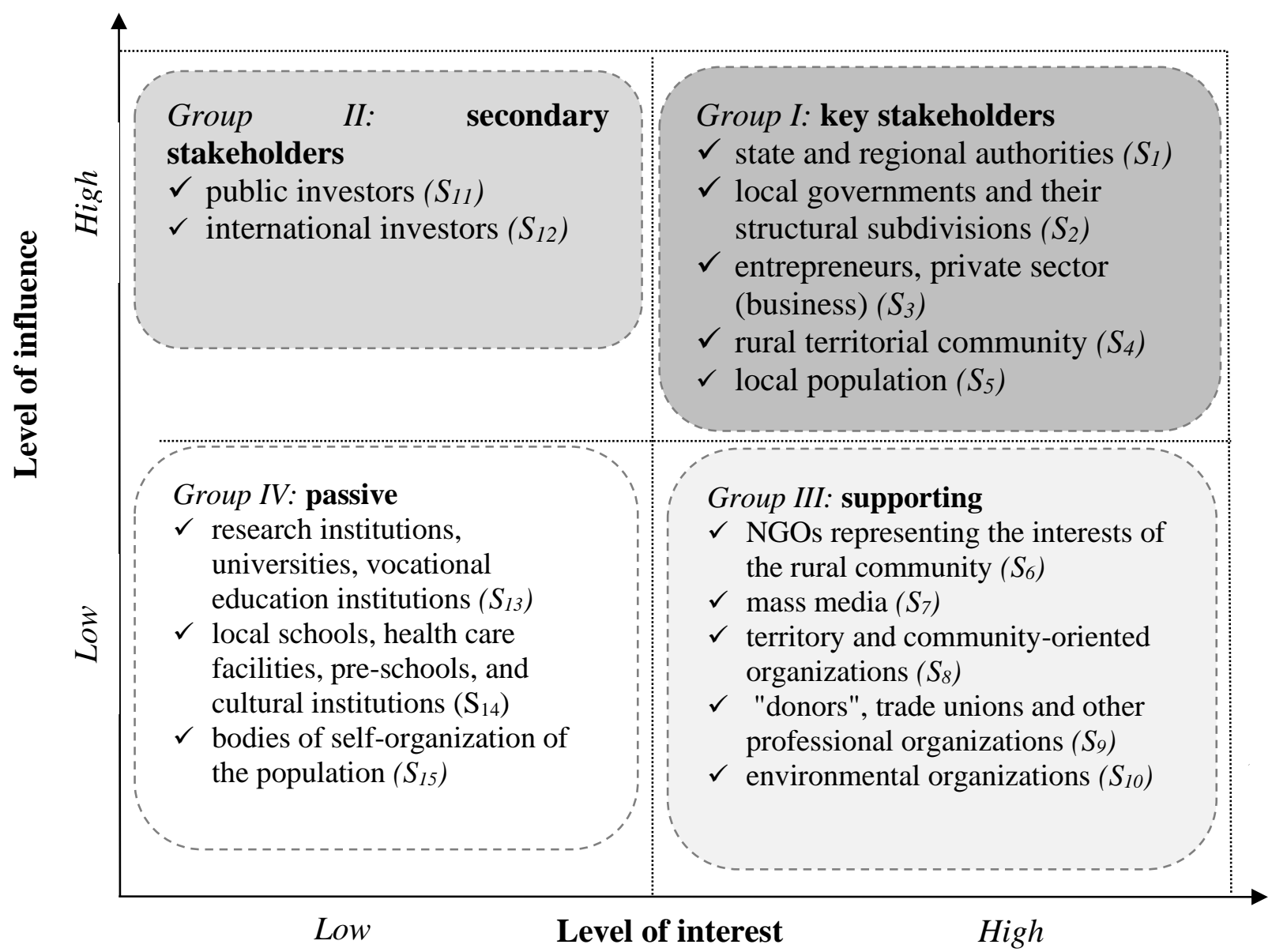

Group III - supporting stakeholders: stakeholders with a high level of interest in the development of the rural economy but with a low level of managerial influence on this process. Stakeholders of this group should be involved in the discussion of important (problematic) issues related to the development of the economic sphere, as they primarily play a supporting role. 
Group IV - passive stakeholders: stakeholders with a low level of influence on the development of the rural economy and at the same time a low level of interest. These stakeholders should be involved in certain tasks without in-depth information on the content of the issue raised. They are secondary to the monitoring and control of their positioning in the market, which is carried out in the presence of the necessary resources.

Involving entrepreneurs in the management process involves the formation of a model, which should be based on the following components: participation, goals, needs, values, effects, risks, and benefits. The choice of tools for involvement depends on the analysis of their feasibility for specific determinants and parameters of rural development. To visualise the content of the motivational interests of individual stakeholders and identify the possibilities of their influence, a corresponding profile was built with a description of the location at the level of the territorial community as the main subject of ensuring the development of the rural economy (Table 3).

Table 3 Profile of stakeholders' influence and interest over rural economy development (location - territorial community)

\begin{tabular}{|c|c|c|c|c|c|c|c|c|c|c|c|c|c|c|c|}
\hline \multirow{2}{*}{$\begin{array}{l}\text { Interest, } \\
\text { influence }\end{array}$} & \multicolumn{15}{|c|}{ Stakeholders } \\
\hline & $S_{1}$ & $S_{2}$ & $S_{3}$ & $S_{4}$ & $S_{5}$ & $S_{6}$ & $S_{7}$ & $S_{8}$ & $S_{9}$ & $S_{10}$ & $S_{11}$ & $S_{12}$ & $S_{13}$ & $S_{14}$ & $S_{15}$ \\
\hline \multicolumn{16}{|c|}{ Motivational interest } \\
\hline \multicolumn{16}{|l|}{$I_{1}$} \\
\hline \multicolumn{16}{|l|}{$I_{2}$} \\
\hline \multicolumn{16}{|l|}{$I_{3}$} \\
\hline \multicolumn{16}{|l|}{$I_{4}$} \\
\hline \multicolumn{16}{|l|}{$I_{5}$} \\
\hline \multicolumn{16}{|l|}{16} \\
\hline \multicolumn{16}{|l|}{$I_{7}$} \\
\hline \multicolumn{16}{|l|}{$I_{8}$} \\
\hline \multicolumn{16}{|l|}{$I_{9}$} \\
\hline \multicolumn{16}{|l|}{$I_{10}$} \\
\hline \multicolumn{16}{|l|}{$I_{11}$} \\
\hline \multicolumn{16}{|l|}{$I_{12}$} \\
\hline \multirow{2}{*}{\multicolumn{16}{|c|}{ Influence }} \\
\hline & & & & & & & & & & & & & & & \\
\hline \multicolumn{16}{|l|}{$V_{1}$} \\
\hline \multicolumn{16}{|l|}{$V_{2}$} \\
\hline \multicolumn{16}{|l|}{$V_{3}$} \\
\hline \multicolumn{16}{|l|}{$V_{4}$} \\
\hline \multicolumn{16}{|l|}{$V_{5}$} \\
\hline \multicolumn{16}{|l|}{$V_{6}$} \\
\hline \multicolumn{16}{|l|}{$V_{7}$} \\
\hline \multicolumn{16}{|l|}{$V_{8}$} \\
\hline \multicolumn{16}{|l|}{$V_{9}$} \\
\hline \multicolumn{16}{|l|}{$V_{10}$} \\
\hline$V_{11}$ & & & & & & & & & & & & & & & \\
\hline
\end{tabular}

Note: $I_{1}$ - improvement of economic, social and environmental indicators of community development; $I_{2}-$ improvement of environment for local development; $I_{3}$ - improvement of the quality of life and welfare of the population; $I_{4}-$ accumulation of public goods; $I_{5}-$ improvement of financial and economic condition; $I_{6}-$ implementation of entrepreneurial initiative; $I_{7}-$ provision of educational and cultural services to the population; $I_{8}-$ accumulation of social capital, social growth; $I_{9}-$ building resource potential; $I_{10}-$ the need for new facilities and platforms for investment; $I_{11}-$ expanding the audience of coverage by information channels; $I_{12}-$ the need to solve local and global environmental problems; $I_{13}$-implementation of economic, social, environmental, institutional projects. $V_{1}-$ the possibility of solving local problems of socio-economic development and identification of new growth vectors; $V_{2}-$ legal and institutional regulation; $V_{3}-$ attraction of financial instruments and levers; $V_{4}-$ rational use of the institutional and legal environment; $V_{5}-$ rational use of resource potential; $V_{6}-$ formation of a favourable information and motivational environment for development; $V_{7}-$ tax revenues to the local budget; $V_{8}-$ initiative efforts and patriotic interest in development; $V_{9}$ - increasing the intellectual, innovative, moral, cultural and psychophysical potential of rural residents; $V_{10}-$ the opportunity for environmental improvement; $V_{11}$ - monitoring and control of socio-economic indicators of rural economy development.

Given that rural economy stakeholders have (potentially have) different interests (economic, social, environmental, informational) and limited or unevenly allocated resources to implement these interests (financial, labour, intellectual, innovative, technological, informational, property, personnel, administrative, etc.), the possibility of both partnership and competitive cooperation should be envisaged. In addition, an important element of the rural economic management system is the relationship between stakeholders in the production, distribution, exchange, and consumption of 
public goods, which requires the separation of stakeholder groups by territorial, sectoral, resource, management, and legal approaches.

European practice has evidenced that it is important to perceive and position stakeholders as partners and not as a separate component of the business environment. This vision of participation is based on the expediency of managing stakeholders in rural development on the basis of bridging - a managerial style of interaction between entities, which allows to obtain a synergistic effect of cooperation with different interests. Bridging is a partnership that can exist in various forms, including joint business with major counterparts, the public, the state within the corporate social responsibility of business (Shevchenko, 2008) (Figure 2).

Figure 2 Participation and bridging for attracting stakeholders

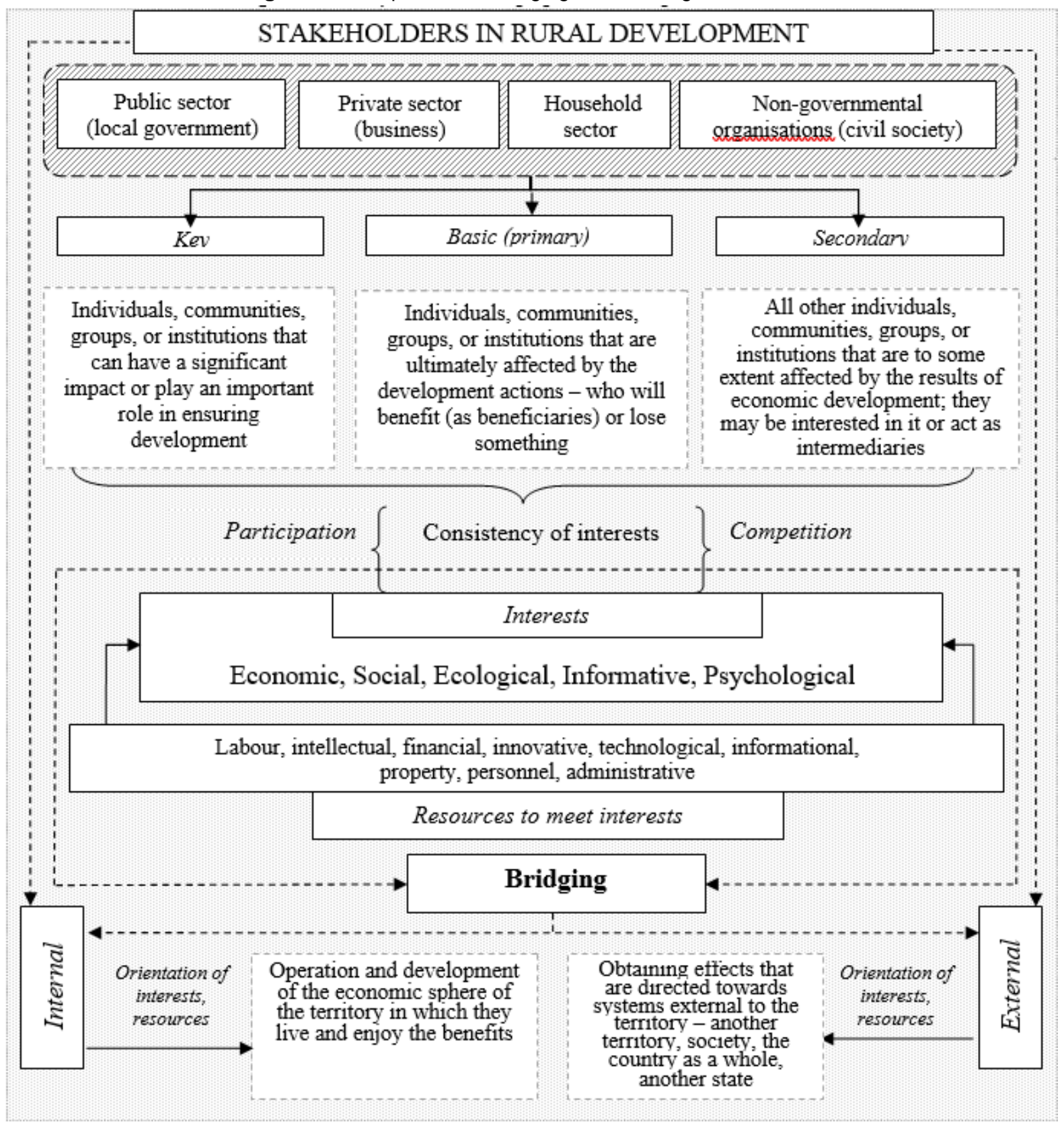

Stakeholder management is a complex process characterised by risk, investment, complexity of implementation, knowledge intensity, which requires consideration of the peculiarities of their participation and cooperation in the formation and implementation of specific projects. Particular care should be taken of the formation of interaction mechanisms and the specifics of the scope of efforts by stakeholders, given their division into internal and external in relation to a particular area. In 
particular, the interests of internal stakeholders are mainly related to the functioning and development of the economy of the territory in which they live and enjoy its benefits. Instead, external stakeholders focus on obtaining effects that will then be directed to external systems relative to the territory another territory, a community, a country as a whole, another state.

The methodology for managing relations with stakeholders in rural development provides for the following stages of this process: 1) identification of stakeholders; 2) their systematisation and prioritisation; 3) assessment of interests, goals, resources; 4) the choice of forms of communication, formalisation of relations; 5 ) analysis of possibilities of coordination of interests of stakeholders with interests of subjects of development of rural economy; 6) the choice of marketing strategy of interaction and participation; 7) evaluation of the effectiveness of interaction and participation.

\section{Conclusion}

The stakeholder-oriented approach is a modern tool for inclusive transformation of rural economy in the context of involving all stakeholders in rural management, ensuring rural well-being, increasing productivity, expanding employment opportunities, access to services and infrastructure, influencing policy and more. Entrepreneurs as key stakeholders in the development of the rural economy are the driver of quality transformation of territories, their branding and promotion among potential investors, the formation of competitiveness and image. Mechanisms for their involvement in management processes should be built on the principles of systematisation, complementarity, transparency, coherence, awareness, sustainability, and strategic direction, which will diagnose their interests, determine the nature and levers of influence, develop effective models of cooperation.

Bridging is a higher form of stakeholder cooperation than the usual relationships formed within rural areas as geographically delineated socio-economic systems and an effective tool for mitigating the negative impact of business factors in the management of the rural economy. Bridging provides systematic, consistent and well-established interaction in the direction of implementing common strategic objectives, interests and goals of rural management. This strategic vector plays an exceptional role in creating an atmosphere of mutual trust, constructive dialogue, accumulation of social capital, formation of corporate culture, development of adequate territorial development strategies against the background of raising the role of public-private partnership as a form of strategic cooperation.

Involvement of entrepreneurs in management processes as stakeholders in rural development is one of the key levers in the formation and implementation of rural development policy in the European Union. The implication of the European experience in the process of formation and development of the rural economy in Ukraine is seen as a necessary attribute of the implementation of its ambitions to participate in the global process of sustainable development.

Prospects for further study in this area are the development of methodological tools for assessing the effectiveness of attracting entrepreneurs in the management of rural economy.

\section{References}

1. AccountAbility. (2015). Stakeholder engagement standard AA1000-SES.

https://www.accountability.org/standards/aa1000-stakeholder-engagement-standard/ [Accessed Dec 25, 2020].

2. AccountAbility. (2018). AA1000 Accountability principles.

https://www.accountability.org/standards/aa1000-accountability-principles/ [Accessed Dec 25, 2020].

3. Belokon, A. I., Malanchiy, S. A., \& Alkubalayt, T. A. (2016). Theoretical aspects of the definition and interaction of stakeholder groups in projects. PDABA Bulletin, 1(214), 72-8.

4. Borodina, O.M., Prokopa, I.V., \& Popova, O.L. (2015). Community-based rural development policy. Kyiv: NASU Institute for Economics and Forecasting. 
5. Carrión, J.J.J., García, J.M.G., \& Arufe, J.E.F. (2020). Social economy and local/rural development. an analysis of synergies. Estudios De Economia Aplicada, 29(1), 189-222.

6. D'anselmi, P. (2011). Values and stakeholders in an era of social responsibility. New York: Free Press.

7. Dashchuk, Yu.Ye. (2013). Methodical approaches to the classification of stakeholders in the development of recreational potential of the region. Collection of Scientific Works of Tavriya State Agrotechnological University, 1, 141-7.

8. Freeman, R.E. (1984). Strategic management: a stakeholder approach. first edition. Boston: Harpercollins College Div.

9. Gupta, J., Pouw, N., \& Ros-Tonen, M. (2015). Towards an elaborated theory of inclusive development. European Journal of Development Research, 27, 541-59.

10. Horban, V.B. (2016). Sustainable energy efficiency management at the local level: a stakeholderoriented approach. Economic Problems, 4, 47-56.

11.International organization for standardization. (2010). International standard ISO 26000: 2010 "Guidelines for social responsibility". http://www.meraua.com/files/ISO_26000_-Rus--draft.pdf. [Accessed Dec 26, 2020].

12.Khoroshun, E.A., \& Nikiforova, L.E. (2017). Stakeholder management as a factor in the formation of key organizational competencies. Innovation Economy Issues, 7(4), 457-70.

13.Korsgaard, S., Müller, S., \& Gaddefors, J. (2018). Resources and bridging: the role of spatial context in rural entrepreneurship. Entrepreneurship and Regional Development, 30(1/2), 224-55.

14.Kravchuk, N., Tarasovych, L., \& Yaremova, M. (2017). Development of the socially-oriented economy in Ukraine: prereguisites and strategic forecasting. Baltic Journal of Economic Studies, $3(2), 66-72$.

15.Kutsmus, N.M. (2018). Gender imperatives of rural economic development in the context of globalization. Kyiv: TsUL.

16.Lahuta, YA.M. (2017). Stakeholder approach in corporate social responsibility of the company. Scientific Bulletin of the International Humanitarian University. Economics and management, 5, 130-3.

17.Levchenko, N.M. (2019). Stakeholder analysis as a tool for effective project management in the context of Ukraine's integration into the European and global business space. Innovative mechanisms for managing corporate integration processes of enterprises. Zaporizhzhia: ZNTU.

18.Lopez, M., Cazorla, A., \& Panta, M. P. (2019). Rural entrepreneurship strategies: Empirical experience in the Northern Sub-Plateau of Spain. Sustainability: Research Papers, 11, 12-43.

19.Méndez, E.G.O., \& Escolar, B.M. (2020). The rural economy in chile: between poverty and development. Estudios De Economia Aplicada, 29(1), 31-55.

20.Post, J., Preston, L., \& Sachs, S. (2002). Redefining the corporation: stakeholder management and organizational wealth. California: Stanford University Press.

21.Preston, L. (2004). Boards and company performance - research challenges the conventional wisdom. Corporate Governance: An International Review, 11(3), 151.

22.Project management institute. (2013). A Guide to the project management body of knowledge (RMBOK Guide). Fifth Edition. Pennsylvania: Project Management Institute, Inc.

23.Ramanauskas, J., Žukovskis, J., \& Zinovchuk, V. (2017). Agricooperatives and producer's organisations: case of EU countries and lessons for Ukraine. Management Theory and Studies for Rural Business and Infrastructure Development: Research Papers, 39(4), 333-46.

24.Rybak, A.I., \& Azarova, I.B. (2017). Stakeholder management in project management. Odesa: ADABA.

25.Shevchenko, L.I. (2008). New dictionary of foreign words: about 40,000 words and phrases. Kyiv: Arii. 
26.Shkromyda, N.YA. (2014). Stakeholders as the main factors influencing the economic potential of the enterprise: the need for their accounting and analysis. Bulletin of Vasyl Stefanyk Precarpathian University. Economics, 10, 83-7.

27.Skydan, O., Nykolyuk, O., Pyvovar, P., \& Martynchuk, I. (2019). Methodological approach to the evaluation of agricultural business system flexibility. management theory and studies for rural business and infrastructure development, 41(4), 444-62.

28.Smachylo, V.V., Kolmakova, O.M., \& Kolomiiets, Yu.V. (2017). The procedure of analysis of stakeholders of the enterprise. Economy and Society, 12. 348-53.

29.Tkachuk, V., Yaremova, M., Tarasovych, L., Kozlovskyi, V., \& Piliavoz, T. (2019). Economic strategy of the development of renewable energy in rural areas of Ukraine. Montenegrin Journal of Economics, 15(3), 71-82.

30.Trivelli, C., \& Berdegué, J. (2019). Rural transformation. Looking towards the future of Latin America and the Caribbean. 2030 - Food, agriculture and rural development in Latin America and the Caribbean. (No. 1). Santiago: FAO.

31.Tryfonova, A.I. (2019). Analysis of existing project stakeholder management models and tools. Open Information and Computer Integrated Technologies, 86, 160-76.

32.United Nations Ukraine. (2015). Sustainable development goals. https://ukraine.un.org/uk/sdgs [Accessed Dec 26, 2020].

33.Vasylchenko, H., Parasiuk, I., \& Yeremenko, N. (2015). Territorial community development planning. Kyiv: Pidpryiemstvo VI EN EI.

34.Wigren-Kristofersen, C., Korsgaard, S., Brundin, E., Hellerstedt, K., Alsos, G.A., \& Grande, J. (2019). Entrepreneurship and embeddedness: dynamic, processual and multi-layered perspectives. Entrepreneurship \& Regional Development, 31(9/10), 1011-5.

35.Zhosan, H.V. (2020). Identification of youth entrepreneurship stakeholders. In: Integración de las ciencias fundamentales y aplicadas en el paradigma de la sociedad post-industrial: colección de

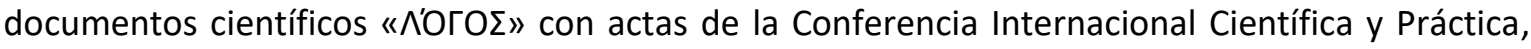
(pp. 48-52). Barcelona: Plataforma Europea de la Ciencia.

36.Zinchuk, T., Kutsmus, N., Kovalchuk, O., Dankevych, V., \& Usiuk, T. (2017). Institutional transformation of Ukraine's agricultural sector. Review of Economic PerspectivesNárodohospodářský Obzor, 17(1), 57-80.

37.Zinovchuk, V., \& Kopytova, I. (2018) A criteria model for assessing the efficiency of the production management. Management Theory and Studies for Rural Business and Infrastructure Development, 40(1), 118-27. 